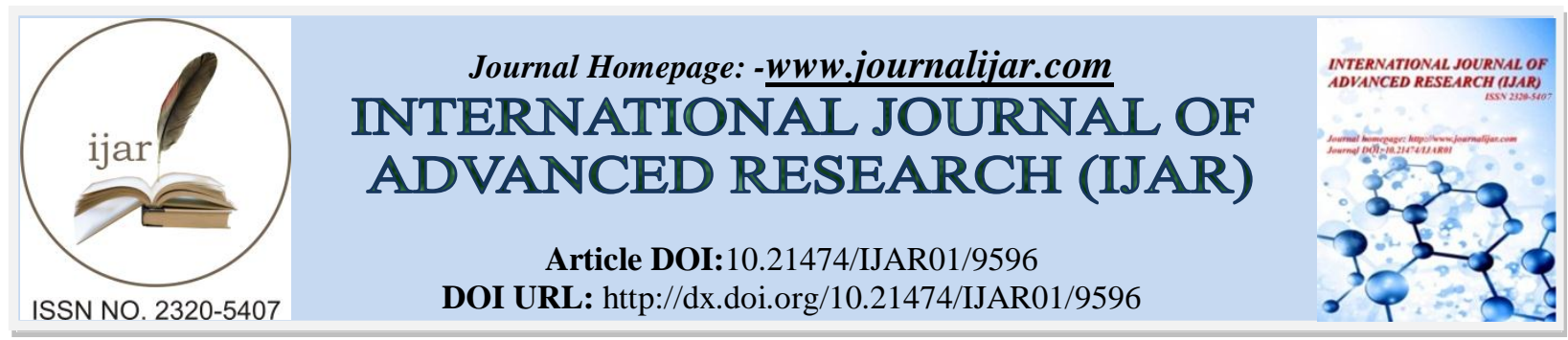

RESEARCH ARTICLE

\title{
INNOVATIONS OF EDIBLE COATING FOR ENHANCEMENT OF SHELF LIFE AND QUALITY MANAGEMENT OF PAPAYA FRUIT (CARICA PAPAYA L.).
}

\author{
NaliniSingh ${ }^{1}$ and Sakshi Chaubal ${ }^{2}$. \\ 1. Msc student, Department of Botany, Institute of Science, Mumbai - 32. \\ 2. Associate Professor, Department of Botany, Institute of Science, Mumbai - 32.
}

\section{Manuscript Info \\ Manuscript History \\ Received: 18 June 2019 \\ Final Accepted: 20 July 2019 \\ Published: August 2019}

\section{Keywords}

Papaya fruit, Aloe Vera Gel, Papaya leaf, Lemongrass leaf, Shelf Life.

\begin{abstract}
The main objective of this study was to increase the shelf life of papaya by using edible coating. Postharvest losses of fruits are a serious problem because of rapid deterioration during handling, transport and storage. Use of edible coatings over fruits is used to improve their quality and self life. To improve the performance of edible coating of Aloe Vera gel various other plant based product were incorporated like papaya leaf and lemon grass. The present study was carried out to evaluate the ability of Aloe gel based antimicrobial coatings to reduce/control the loss of post harvest fruit quality in papaya and to compare the effects with papaya leaf and lemongrass along with aloe vera gel, an established coating material with antifungal activity. Freshly harvested papaya fruits were coated with 50\% Aloe gel/AG, papaya leaf extract/PLV incorporated Aloe gel (1:1) and Lemongrass leaf extract/L.V incorporated Aloe gel (1:1). The coated and uncoated (control) fruits were stored at $30 \pm 3^{\circ} \mathrm{C}$ and $42-55 \% \mathrm{RH}$ for $10 \mathrm{~d}$. Physiological loss in weight, Titrableacidity, $\mathrm{pH}$, pectin content, and sensory characteristics (color, taste \& firmness) were analyzed at regular intervals during the storage period. The coated fruits survived the storage period of 10 day, whereas, all the uncoated controls decayed within 5 day. Among the coated fruits, PLE.AG treated fruits exhibited least changes followed by Aloe vera gel and LV.AG coated fruits.
\end{abstract}

Copy Right, IJAR, 2019,. All rights reserved.

\section{Introduction:-}

One of the major growth segments in the food retail industry is fresh and minimally processed fruits and vegetables. This new market trend has thus, increased the demands for the food industry for finding new strategies to increase storability and shelf -life and to enhance microbial safety of fresh produce. The most important quality attributes contributing to the marketability of fresh and minimally processed produce include appearance, colour, texture, flavor, nutritional value, and microbiological safety. These quality attributes are determined by plant variety, stage of maturity or ripening and the pre and post harvest condition and al lcan change rapidly during postharvest storage (Lin,D.andZhao,Y.2007). In general, desiccation and decay are the two major causes of the termination of commercial life span of fruits and vegetables. The water loss resulting from transpiration causes not only shrinkage and wilting, but also softening of produce. Papaya is one of the major

Corresponding Author:-NaliniSingh.

Address:-Msc student, Department of Botany, Institute of Science, Mumbai - 32. 
tropical fruits of India. The desiccation of fruits and perishable nature of papaya is a major drawback during transportation to distant markets and storage during glut in market. The estimated post-harvest losses of papaya fruits in India has been reported to be between 40-100\% (V.Singhal,1999). The different storage methods used to preserve papaya fruits include low temperature storage, controlled atmospheric storage, plastic film wraps and wax coatings. But there are many reports that papaya in refrigerated storage is susceptible to fungal decay (S. Mitra, 2005). In controlled atmosphere storage, papaya fruits were benefitted only slightly from storage in low oxygen (1-

$1.5 \%$ ) conditions, at $13^{0} \mathrm{C}$ (J.Mattheis \& J.K. Fellman, 2000). Polymeric films and wax coatings were found to be effective in reducing water loss from papaya but were not effective in preventing fruit decay (S. Mitra, 2005). There are few studies on the efficiency of edible coating to reduce the perishability of papayas. Application of various semi permeable edible coatings has been found to be satisfactory way of achieving modified atmospheres. These coating include a mixture of fatty acids and carboxy-methylcellulose, and commercial coating. Fruits coating with these edible coating were reported to extend the shelf life and delay the onset of fungal infection. (S.Mitra, 2005). Chitosan, a modified natural biopolymer, with broad antimicrobial activit y and film forming property has also been reported to be effective in extending the shelf life of papaya. There is, hence scope to study economically viable alternatives to improve the shelf life of papaya fruits using other edible coating that are biodegradable and eco-friendly. Recently, there has been increased interest in using "Aloe Vera "gel as an edible coating material for fruits and vegetable driven by its antifungal activity. (Valverde et al.,2005; Martinez-Romero et al., 2007). Aloe Vera has medicinal properties, is a tropical and subtropical plant that has been used from ancient time (Eshun et al., 2004). The gel of Aloe Vera leaves is the colorless mucilaginous, obtained from the parenchymatous cells. Application of Aloe Vera gel in the food industry is increasing day by day as resource of drinks, beverages and ice creams (Eshun and He, 2004).AloeVeraisastemlessandveryshortstemmedsucculentplantbelongstofamily Liliaceae (Surjushe A, 2008 and Ni et al., 2004). The medical uses of the Aloe gel juice (orally) are against skin diseases, constipation, radiation injury gastrointestinal, kidney and cardiovascular problems (Leila Akbari et al., 2013), reduce the cholesterol and triglyceride levels in blood. Recently other important property of Aloe Vera has been reported such as anti- inflammatory and antibiotic activities against some diseases like diabetics, cancer, allergy and AIDS (Eshun et al., 2004; Reyhlds et al., 1999; Arowora et al., 2013). Aloe Vera gel is also used in the cosmetic industry, including treatment of burns and scars and in wound healing (Aburjai et al., 2004). The antifungal activity of Aloe Vera gel has observed against several pathogenic fungi. Edible coatings have been used since ancient time to protect perishable food stuffs from deterioration by retarding dehydration, suppressing respiration, improving textural quality to retain volatile flavor compounds, and reducing microbial growth (Debeaufort et al. 1998; Ozdemir et al.2010). Due to consumer demand for food without chemical preservatives has resulted in application of natural antimicrobials preservatives and antimicrobial films and fungicide application can be reduced (Elmer and Reglinski, 2006). To avoid fruit spoilage it is essential to preserve fruits and it has been estimated that around $25 \%$ to $80 \%$ of harvested fresh fruits are wasted due to spoilage (Quezada et al., 2003). There are natural preservatives which are used as edible surface coatings for vegetables and fruits such as waxes but these coatings commonly contain ingredients such as polyethylene, carnauba and candelilla (Hagenmaier and Baker, 1995; Debeaufort et al., 1998; Alleyne and Hagenmaier, 2000). Amarante et al. (2001); Jeong et al., (2003) have studied wax coating as fruits preservatives and increase the shelf life, slows down ripening, retards water loss, reduces decay and enhances visual quality. The Aloe gel is made up of water, amino acids, vitamins, lipids, sterols, tannins, and enzymes (Shelton, 1991) and contains phenol, saponin, anthraquinones components, have anti-bacterial, antiviral and antifungal properties. Aloe Vera has shown antibacterial property against gram positive and gram negative pathogens (Adetunji, 2008). Aspergillus, Fusarium and Penicillium are fungal species which are responsible for oxidation and spoilage of food (A. Babaei et al., 2013). Aloe Vera can be applied as edible coatings for fruits as its biological activities prevent loss of moisture, firmness, control respiration rate and maturation development, delay oxidative browning, and reduce microorganism proliferation. (Valverde et al., 2005; Matinez Romero et al., 2005; Ahmed et al.,2009). Extract of papaya leaves and lemon grass leaves have been reported to possess antimicrobial activity against fungal pathogen. (Abirami L.S.S, 2009). There are reports present of post harvest application of Aloe Vera coating on papaya fruits but with comparison with chitosan coating. A study was hence conducted to evaluate the effect of Aloe Vera gel and papaya leaf extract incorporated Aloe Vera gel coating on the storage life of papaya fruits in comparison to lemongrass leaf extract incorporated Aloe Vera gelcoating. 


\section{Materials and methods:- \\ Collection of samples:-}

Freshly harvested papaya (Carica papaya L.) fruits were procured or obtained from the local market of Vashi, Mumbai. They were selected on the basis of size, colour and absence of external injuries and marks. Fresh papaya leaves and Aloe Vera leaves were obtained from the Institute of Science campus garden and fresh lemongrass leaves were obtained from the local market.

\section{Preparation of edible coatings:-}

Preparation of Aloe Veragel:-

Matured leaves of Aloe Vera plant was harvested and washed with a mild chlorine solution of 25\% (Shweta Chauhan1, et al, 2014). Aloe Vera gel matrix was then separated from the outer cortex of leaves and this colorless hydro-parenchyma was grounded in a blender and resulting mixture was filtered to remove the fibers, and fresh Aloe Vera gel was obtained $(1000 \mathrm{ml})$. The gel matrix was pasteurized at $70{ }^{0} \mathrm{C}$ for $45 \mathrm{~min}$. The gel was cooled immediately for stabilization and ascorbic acid (2.0g L-1), citric acid (4.5 gL-1) was added to maintain the $\mathrm{pH}$ at 4. The viscosity of the stabilized Aloe Vera gel and its coating efficiency was improved by using 1\% (agar) commercial gelling agent ( Marpudi et al; 2011) and stored in brown Amber bottle to prevent oxidation of the gel (He et al., 2005 and Adetunji et al 2012). This is used as Aloe Vera gel (AG) coating.

Preparation of Papaya leaf extract and lemongrass extract incorporated Aloe Vera gel coating respectively:To prepare Papaya leaf extract incorporated Aloe Vera gel coating (PLV.AG), $100 \mathrm{~g}$ of papaya leaves were surface sterilized for $5 \mathrm{~min}$ in $0.1 \% \mathrm{HgCl}_{2}$, and then washed thoroughly with distilled water. The leaves were then crushed along with Aloe gel and there extract was filtered and made up to $100 \mathrm{ml}$ with Aloe gel. (Marpudi et al. 2011).

Same as the preparation of papaya leaf extract incorporated Aloe Vera gel coating (PLV.AG), lemongrass leaf extract incorporated Aloe Vera gel coating (LEAG) was prepared, i.e. $100 \mathrm{~g}$ Lemongrass leaves were surface sterilized for $5 \mathrm{~min}$ in $0.1 \% \mathrm{HgCl}_{2}$, and then washed thoroughly with distilled water. The leaves were then crushed along with Aloe gel and there extract was filtered and made up to $100 \mathrm{ml}$ with Aloe gel.

\section{Application of edible coating solution onPapaya:-}

The coating solution used for papaya fruits were 50\% Aloe Vera gel, PLV.AG (1:1), and LEAG (1:1).The fresh fruits were dipped completely into the coating solution at room temperature for 15 minutes. They were allowed to drain and then dried at room temperature using a forced air dryer so that a thin film layer is formed on the fruits. Six fruits were used for each coatingsolution.

\section{StorageProcedure}

The fruits were then weighed and stored in wooden container lined with newspaper at room temperature $\left(30 \pm 3^{\circ} \mathrm{C}\right)$ (Marpudi et al. 2011). The experiments were replicated for each coating. Fruits without coating were used as control and were stored under same condition as those for coated fruits.

\section{Antibacterial and Antifungal activity:-}

One bacterial culture, Escherichia coli and one fungal culture, Aspergillus niger were utilized for performing the antibacterial and antifungal activity. The antibacterial and antifungal activity of papaya leaf, Aloe Vera leaf and lemongrass leaf was determined by disc diffusion method by Bauer et al. (1966).

$5 \mathrm{~mm}$ diameter discs were prepared using sterile Whatman No.1 filter paper. The discs was impregnated with $20 \mu 1$ of different solvent extracts of papaya leaf, Aloe Vera leaf and lemongrass leaf at four different concentration ranging $1 \mathrm{mg} / \mathrm{ml}, 2 \mathrm{mg} / \mathrm{ml}, 3 \mathrm{mg} / \mathrm{ml}, 4 \mathrm{mg} / \mathrm{ml}$ to check their antibacterial and antifungalactivity. The zone of inhibition was observed and measured inmillimeters.

\section{Phytochemical analysis:-}

Qualitative phytochemical tests for the identification of alkaloids, flavonoids, steroids, tannins, terpenoids, saponins, glycosides, phenols and proteins were carried out in the extract as per the method described by Harborne (1973), Sofowora (1993) and Trease and Evans (1989). 


\section{Physiological Loss in weight (PLW):-}

For determining PLW (Water loss) of all Papayas, the weight of the papayas was recorded and the total loss of physiological weight was then calculated by subtracting the final weight of the vegetables from the initial weight. The results were then expressed in percentage using following formula: (A-B)/A x100, (Marpudi et al; 2011).

Where, A is the initial weight of fruits ( 0 day) and $\mathrm{B}$ is the fruit weight after the storage period.

\section{TitrableAcidity:-}

At the beginning of the ripening process the sugar/acid ratio is low, because of low sugar content and high fruit acid content, this makes the fruit taste sour. During the ripening process the fruit acids are degraded, the sugar content increases and the sugar/acid ratio achieves a higher value. Overripe fruits have very low levels of fruit acid and therefore lack characteristic flavour. For the estimation of Titrable acidity, fruits (longitudinal section of fruit was used) were homogenized and the resultant pulp was filtered. Weigh $10 \mathrm{ml}$ of squeezed fruit juice into a conical flask and dilute to $50 \mathrm{ml}$ with distilled water. Titrate the sample against $0.1 \mathrm{~N} \mathrm{NaoH}$ by using phenolphthalein as indicator. The result was expressed as \% total acid (Titrable Acidity). TA was determined according to the method as described by S.Ranganna(1995).

Titrable acidity $=\frac{\mathrm{D} \times 0.064\left(\mathrm{NaOH} \text { sol }^{\mathrm{n}} \text { is }^{0.1 \mathrm{~N})} \times \mathrm{C}\right.}{\mathrm{A} \mathrm{XB}} \quad \mathrm{X} 100$

Where,

$\mathrm{A}=$ Weight of the sample. $\mathrm{B}=$ Volume of the sample taken for examination. $\mathrm{C}=$ Volume of the sample made with distilled water. $\mathrm{D}=$ Burette reading.

pH:-

Fruits (longitudinal section of fruit was used) were homogenized and the resultant pulp was filtered. The $\mathrm{pH}$ of the fruit juice was determined by using a digital $\mathrm{pH}$ meter.

\section{Sensory Analysis for evaluating fruitquality:-}

Sensory analysis was carried out by 5 selected panelists (selected panelist where Msc botany students). The fruits were randomly selected from each batch and served on white plates. The sensory quality of each batch of fruits was evaluated visually in terms of and fruit firmness.

For peel colour (5- bright green, 4-<25\%yellow, 3- > 30\%to <50\%yellow, 2- 50\% to <75 \%yellow, 1- >75 \%yellow).

For fruit firmness (5- very firm, 4- firm, 3- moderately firm, 2- soft, 1 - very soft).

Fruit taste was evaluated by 5 point hedonic scale (Hedonic scale term used in tasting panels where the judges indicate the extent of their like or dislike for the food.). I.e. from 5- very sweet, 4- sweet, 3-moderately sweet,2-little bland, 1- bland) as an indicator of respiration rate and ripening.

\section{Estimation of pectin by GravimetricMethod:-}

Weigh $50 \mathrm{~g}$ of blended sample into a $1 \mathrm{~L}$ beaker and add $300 \mathrm{ML} 0.01 \mathrm{~N}$ HCL. Boil for $30 \mathrm{~min}$ and filter under suction. Wash the residue with hot water and collect thefiltrate.To the residue add $100 \mathrm{ml}$ of $0.05 \mathrm{~N} \mathrm{HCL}$, boil for 20 min filter, wash and collect the filtrate.To the residue now add $100 \mathrm{ml}$ of $0.3 \mathrm{~N} \mathrm{HCL}$, boil for $10 \mathrm{~min}$, filter, wash and collect the filtrate.Cool the filtrates. Cool and make to volume $(500 \mathrm{ml})$ by using distilledwater.Pipette out 100 to $200 \mathrm{ml}$ aliquots into 1Lbeakers. Add $250 \mathrm{ml}$ water and neutralize the acid with $1 \mathrm{~N} \mathrm{NaOH}$ using phenolphthalein indicator. Add an excess of $10 \mathrm{ml}$ of $1 \mathrm{~N} \mathrm{NaOH}$ with constant stirring and allow it to standovernight.Add $50 \mathrm{ml} 1 \mathrm{~N}$ acetic acid and after $5 \mathrm{~min}$, add $25 \mathrm{ml} 1 \mathrm{~N}$ calcium chloride solution with stirring. Allow it to stand for 1 hour. Boil for 1 to $2 \mathrm{~min}$. Filter through a pre-weight Whatman no.1 filter paper (wet the filter paper in hot water, dry in oven at $102^{0} \mathrm{C}$ for 2 hours. Cool in desiccators and weigh in a covereddish). Wash the precipitate with almost boiling water until the filterate is free fromchloride. Test the filtrate with silver nitrate forchloride. Transfer the filter paper with the calcium pectate, dry overnight at $100^{0} \mathrm{C}$ in a weighing dish, cool in a desiccators and weigh. 


\section{Calculation:-}

The pectin content is expressed as \% calcium pectate:-

$\%$ calcium pectate $=$ wt. of calcium pectate $\mathrm{x} 500 / \mathrm{ml}$ of filtrate taken $\mathrm{x}$ wt. of sample for estimation $\mathrm{x} 100$.

\section{Statisticalanalysis:-}

The data obtained from the experiment were expressed as Mean \pm S.E (Standard error). One- way analysis of variance (ANOVA) was used to evaluate the significant differences between observations wherever necessary. The criterion of $\mathrm{P}$ value $<0.05$ wasemployed.

\section{Results:-}

Antimicrobial activity:-

Antimicrobial activity of Papaya leaf, Aloe Vera leaf and Lemongrass Leaf on E.coil and Aspergillus niger with increase in the concentration of compound there is an increases in the zone of inhibition as shown in table no.1and 2 and respectively.

\section{Phyto-chemical analysis:-}

Phytochemical analysis was carried out to find out the chemical constituent present in Papaya leaf, Aloe Vera leaf, Lemongrass Leaf and Papaya fruit. The presence and absence of secondary metabolite has been featured in table no 3.

\section{Physicalcharacteristic:-}

Abnormal loss of firmness due to over ripening and pitting of the skin causes changes in the weight and size of the fruits. The effect of the selected edible coating on physiological loss of water was observed. Physiological loss of water during storage was found to be significantly $(\mathrm{P}<0.05)$ different among the papaya fruits treated with the three different coating and from control fruits at the end of the 10 day storage (table 6 and figure no. C). Physiological loss of water was observed to be $13 \%, 5 \%, 3 \%, 7 \%$ for Control, Aloe Vera, PLV.AG, L.E.A.G respectively.

\section{Chemical characteristic:-}

The value of the chemical parameter such as $\mathrm{pH}$ and Titrable Acidity (TA) was determined as shown in the table 4 and 5 and fig. no A and B respectively. The mean $\mathrm{pH}$ value of the fruits on the initial day was 5.7 and was found to be increased to $7.0 \pm 0.05$ after $10^{\text {th }}$ day of storage in control. In Aloe Vera, PLV.AG, L.E.A.G coated fruits there was minimal change in $\mathrm{pH}$ values. Titrable acidity in the fruits samples decreased with storage time in both control and treated fruits. However the difference was to a lesser extent in coated fruit as compared to control. Titrable acidity values were found to be $0.075,0.15,0.25$, and 0.17 for control, Aloe Vera, PLV.AG, and L.E.A.G coated fruit respectively, as compared to the initial value of 0.30 .

\section{Sensory characteristic:-}

Colour, Firmness and Taste, the major sensory attributes, were scored by panel member (table no 7). Colour was evaluated based on the peel colour with ' 5 ' as a score for green to a scoreof' 1 'forcompleteyellowness.Brightgreencolourofpapayapeelchangedtoyellow. During storage in both control and coated fruits except in PLV.AG coated fruits. The control fruit had shown a greater degree of yellowness by the $5^{\text {th }}$ day. Colour values were given as, 3, 4 and 3 for, Aloe Vera, PLV.AG, and L.E.A.G coated fruit respectively, after $10^{\text {th }}$ day of storage. Firmness values were observed to be 1.0, 2.5, 4and 2.0 for control, Aloe Vera, PLV.AG, and L.E.A.G coated fruit respectively, stored up to $10^{\text {th }}$ day. Taste values were found to be, $4 \pm 0,3 \pm 0.25$ and $4.5 \pm 0.35$ for, Aloe Vera, PLV.AG, and L.E.A.G coated fruit respectively. The mean values of coated fruits for these parameters were significantly $(\mathrm{P}<0.05)$ different from control.

\section{Pectin content:-}

The pectin content is expressed as \% calcium pectate has been expressed in table no 8 and fig. no D. Pectin in the fruits samples decreased with storage time in both control and treated fruits. However the difference was to a lesser extent in coated fruit as compared to control. Pectin value (in\% calcium pectate) were found to be $16 \%, 48 \%, 58 \%$, and $36 \%$ for control, Aloe Vera, PLV.AG, and L.E.A.G coated fruit respectively, as compared to the initial value of $80 \%$.The significant decrease in pectin content with increasing days might be because, when fruit over ripens the pectin content decreases as pectin turns to pecticacid. 


\section{Discussion:-}

Quality of fruit deteriorates as the storage period increases number of factor play significant rate in it. One of them is microbial infection.

In the present study Aloe-Vera gel exhibited maximum efficiency against E coli followed by papaya leaf and lemon grass (Aqil F, Ahmad, 2007).Maximum acidity was observed at highest concentration of extract. Both papaya leaf extract \&Aloe Vera gel \& lemon grass exhibited considerable activity against the fungus A.niger (Baskaran et al 2012) also reported similar finding.

Aqueous plant extracts were also analyzed for phytochemical constitutes (Table no.3). All the plant extract exhibited presence of important phytoconstituents except few like saponins were absent in lemon grass and papaya fruit. Glycosides were not present in papaya leaf \& lemon grass similar results have been observed by Aishwarya Balakrishnan et al, 2015.

$\mathrm{pH}$ of fresh papaya fruit was acidic ( Table no. 4) papaya fruit extract showed negligible $\mathrm{pH}$ change at the end of the $10^{\text {th }}$ day in papaya leaf extract incorporated with Aloe Vera. However $\mathrm{pH}$ control was increased to 7, indicating deteriotiation of fruit quality when the storage period was increased. Similar result was observed and reported by (Marpudi et al; 2011) for papaya.

Titrable acidity also showed similar trend (Table no 5). Where in extract of papaya leaf incorporated with Aloe Vera gel did not show much variation at $10^{\text {th }}$ day as compared with initial titrable acidity value. Similar result has been reported by Anay et al (2009) for apple.

The changes in Titrable Acidity are significantly affected by the rate of metabolism especially respiration, which consumed organic acid and thus declined acidity during the storage (Clarkand McGlone, 2003). Table no 5 shows the changes in TA of papaya fruit with the increase of storage time with differentcoating.

Physiological loss in weight which is one of the significant properties in case of perishable fruit reveals maximum loss in control (Table no 6). It was least in papaya leaf incorporated with Aloe Vera gel. Maintenance of fruit firmness could be related to physiological loss in weight as reported earlier in sweet cherry - Yaman et al (2002) treated with edible coating and Aloe gel coated nectarine fruit - Ahmed, Singh \& Khan (2009).

Sensory qualities of papaya fruit revealed considerable achievement when edible coating was used. (Table no. 7).

The pectin content is expressed as \% calcium pectate has been expressed in table no 8. Pectin in the fruits samples decreased with storage time in both control and treated fruits. However the difference was to a lesser extent in coated fruit as compared to control. Polygalacturonase activity is responsible for pectin solublization and depolymerization in the late stage of ripening (Langley et al, 1994, melon). Thus there is a significant decrease in the pectin content in both coated and uncoated (control) fruit.

\section{Conclusion:-}

In the present investigation an attempt was made to enhance shelf life of Papaya using Aloe gel as well as Aloe gel as base integrated with Papaya leaf and Lemongrass as well. Different parameters like Antimicrobial properties (of Papaya leaf, Lemongrass and Aloe Vera leaf), Phytochemical analysis (of Papaya leaf, Lemongrass and Aloe Vera leaf and papaya fruit), $\mathrm{pH}$, Titrable acidity, Physiological loss in weight, Sensory qualities and Pectin were selected to study the consequence of storage period on Papaya fruits. All the plant extract exhibited antimicrobial activity, maximum efficacy was found in Aloe Vera leaf. The plant extracts (Papaya leaf, Lemongrass and Aloe Vera leaf and papaya fruit) were analyzed for Qualitative presence of Tannins, Saponins, Flavonoids, Phenols, Alkaloids, Terpenoids, Glycosides, Steroids and Proteins.

$\mathrm{pH}$ and Titrable acidity were chosen as the quality of fruit. Papaya leaf extract incorporated with Aloe gel base did not show much variation even at the end of $10^{\text {th }}$ day. Physiological loss in weight is an imperative property in case of perishable fruit; maximum loss was reported in control while the lost was least in Papaya leaf integrated with Aloe 
gel. Sensory quality of Papaya fruit showed remarkable achievement with edible coating. Papaya leaf integrated with Aloe gel exhibited noteworthyresults.

Pectin was insufficiently present in control as compared to the edible coating. Whereas the amount of pectin showed slight difference in Papaya leaf integrated with Aloe gel, which might be due to increase in Polygalacturonase activity with the increase in storage period causes diminish of pectin in Papaya fruit.

Encouraging result about enhancing shelf life of Papaya fruit were obtained in the present study. Farmers and traders should be informed about the edible coating and also should be educated regarding the technique to be used for the preparation and application.

Thus there is a hope that the increase in shelf life would pave the way for farmers and traders to export the fruits and earn revenue for the country.

\section{Acknowledgement:-}

I would like to express my sincere gratitude to my college, THE INSTITUTE OF SCIENCE for letting me to fulfill my dreams of being a student here. I would like to express my deepest appreciation to my project guide $\mathbf{D r}$. (Mrs.) Sakshi chaubal. I especially want to thank my family and friends who were very supportive throughout the project and helped me a lot in their own possible way.

Table no 1:-Zones of inhibition in millimeters $(\mathrm{mm})$ obtained against the test organism

\begin{tabular}{|c|c|c|c|c|}
\hline \multirow{2}{*}{$\begin{array}{c}\text { Plant } \\
\text { extracts }\end{array}$} & $1 \mathrm{mg}$ & $2 \mathrm{mg}$ & $3 \mathrm{mg}$ & $4 \mathrm{mg}$ \\
\cline { 2 - 5 } & & & 10 & 12 \\
\hline Papaya leaf & 5 & 8 & 7.5 & 8 \\
\hline $\begin{array}{c}\text { Lemon } \\
\text { grass }\end{array}$ & 5 & 7 & 8 & 16 \\
\hline Aloe Vera & 6 & 8 & & \\
\hline
\end{tabular}

Table no 2:-Zones of inhibition in millimeters $(\mathrm{mm})$ obtained against the test organism

\begin{tabular}{|c|c|c|c|c|}
\hline \multirow{2}{*}{ Plant extracts } & \multicolumn{3}{|c|}{ Concentration (mg/ml)/zone of inhibition(mm) } \\
\cline { 2 - 5 } & 1 & 2 & 3 & mg \\
Papaya leaf & $\mathrm{mg}$ & $\mathrm{mg}$ & 12 & $\mathrm{mg}$ \\
\hline Lemon grass & 7 & 9 & 9 & 16 \\
\hline Aloe Vera & 6 & 7 & 14 & 15 \\
\hline
\end{tabular}

Table no 3:-Phytochemical screening of secondary metabolites

\begin{tabular}{|c|c|c|c|c|c|}
\hline Compounds & Observation & $\begin{array}{l}\text { Papaya } \\
\text { leaf }\end{array}$ & Lemongrass & $\begin{array}{l}\text { Papaya } \\
\text { fruit. }\end{array}$ & $\begin{array}{l}\text { Aloe } \\
\text { Vera }\end{array}$ \\
\hline Tannins & $\begin{array}{l}\text { Appearance of brownish } \\
\text { green or blue black } \\
\text { colour }\end{array}$ & + & + & + & + \\
\hline Saponins & Formation of stable foam & + & + & - & + \\
\hline Flavonoids & $\begin{array}{c}\text { Appearance of orange } \\
\text { red colour }\end{array}$ & + & + & - & + \\
\hline Phenols & $\begin{array}{c}\text { Appearance of green } \\
\text { blue colour }\end{array}$ & + & + & + & + \\
\hline Alkaloids & Turbidity or precipitation & + & + & + & + \\
\hline Terpenoids & $\begin{array}{l}\text { Reddish brown or } \\
\text { pinkish brown ring or } \\
\text { colour }\end{array}$ & + & + & + & + \\
\hline
\end{tabular}




\begin{tabular}{|l|l|l|l|l|l|}
\hline Glycosides & Brown ring & - & - & + & + \\
\hline Steroids & $\begin{array}{l}\text { The upper layer turns red \& } \\
\text { H2 SO4 showed yellow } \\
\text { fluorescence. }\end{array}$ & + & - & + & + \\
\hline Proteins & White precipitation & + & + & + & + \\
\hline
\end{tabular}

Presence of phytochemical compound:+ Absence ofphytochemical compound: $\quad-\mathrm{pH}$

Table No 4:-pH of the edible coated Papaya and uncoatedPapaya.

\begin{tabular}{|c|c|c|c|c|}
\hline $\begin{array}{c}\text { Storage Period } \\
\text { (Days) }\end{array}$ & Control & Aloe Vera & PLV.AG & L.E.A.G \\
\hline 0 Day & $5.7 \pm 0$ & $5.7 \pm 0$ & $5.7 \pm 0$ & $5.7 \pm 0$ \\
\hline 5 Day & $5.80 \pm 0$ & $5.75 \pm 0$ & $5.72 \pm 0$ & $5.79 \pm 0$ \\
\hline 10 Day & $7.0 \pm 0.05$ & $5.91 \pm 0.01$ & $5.78 \pm 0$ & $6.2 \pm 0.02$ \\
\hline
\end{tabular}

Aloevere

Fig no A:- Effect of Control and Edible coating on $\mathrm{pH}$ of Papaya fruit.

pH

PLV.AG = Papaya leaf extract incorporated in Aloe gel.

L.E. $A G=$ Papaya leaf extract incorporated in Aloe gel.

Table No 5:-Titrable acidity (\%) of the edible coated Papaya and uncoated Papaya.

\begin{tabular}{|c|l|l|c|c|}
\hline $\begin{array}{c}\text { Storage Period } \\
\text { (Days) }\end{array}$ & Control & Aloe Vera & PLV.AG & L.E.A.G \\
\hline 0 Day & $0.3 \pm 0$ & $0.3 \pm 0$ & $0.3 \pm 0$ & $0.3 \pm 0$ \\
\hline 5 Day & $0.15 \pm 0$ & $0.22 \pm 0$ & $0.27 \pm 0$ & $0.20 \pm 0$ \\
\hline 10 Day & $0.075 \pm 0.017$ & $0.15 \pm 0$ & $0.25 \pm 0$ & $0.17 \pm 0.01$ \\
\hline
\end{tabular}




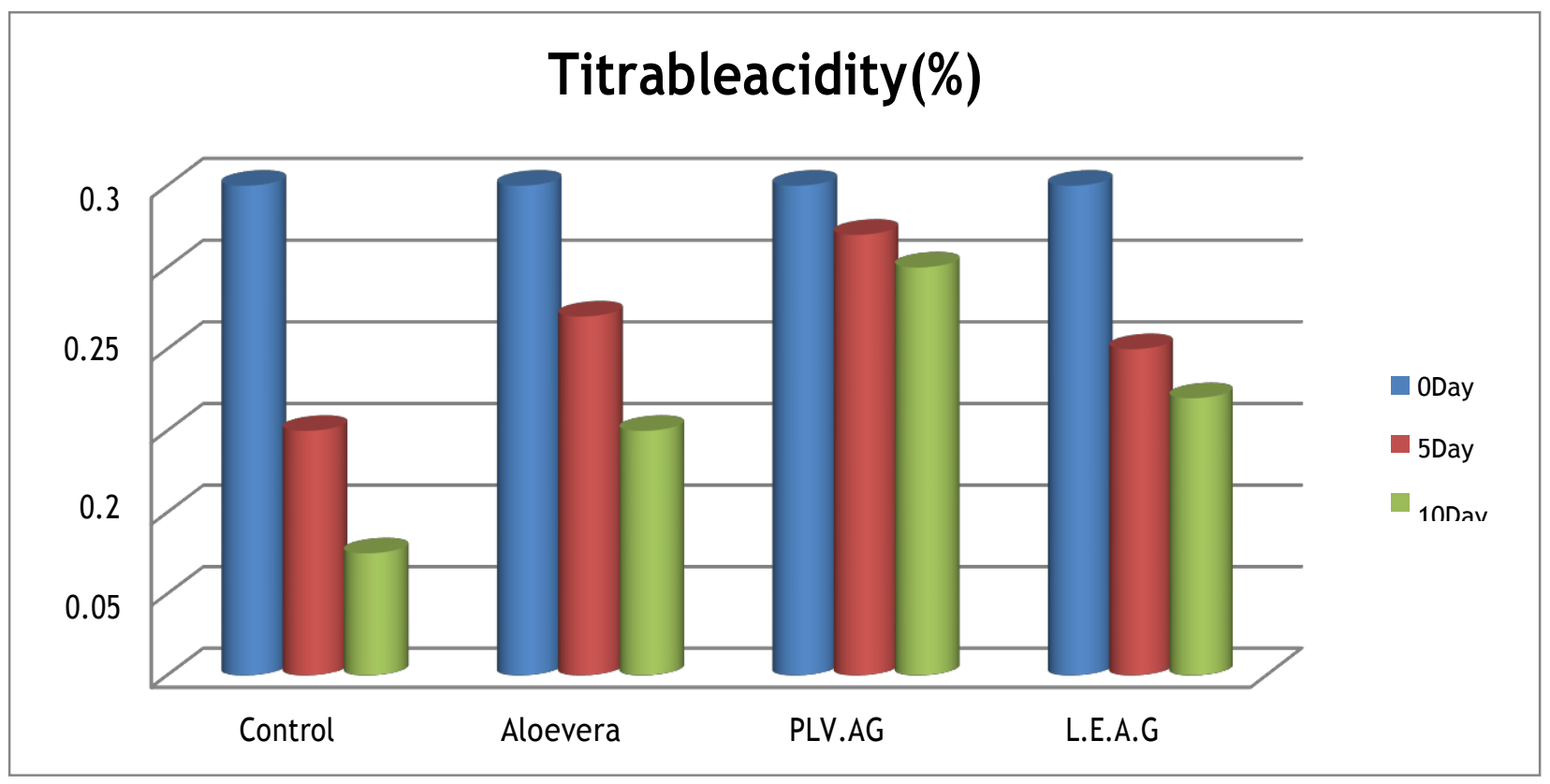

Fig no B: - Effect of Control and Edible coating on Titrable acidity of Papaya fruit.

PLV.AG = Papaya leaf extract incorporated in Aloe gel.

L.E. AG = Papaya leaf extract incorporated in Aloe gel.

Table No 6:-Physiological loss in weight:-

\begin{tabular}{|c|c|c|c|c|}
\hline $\begin{array}{c}\text { Storage Period } \\
\text { (Days) }\end{array}$ & Control & Aloe Vera & PLV.AG & L.E.A.G \\
\hline 5 Day & $8.2 \pm 0.15$ & $3.19 \pm 0.21$ & $2.815 \pm 0.22$ & $3.76 \pm 0.31$ \\
\hline 10 Day & $13.1 \pm 0.14$ & $5.22 \pm 0.02$ & $3.35 \pm 0.10$ & $6.6 \pm 0.42$ \\
\hline
\end{tabular}

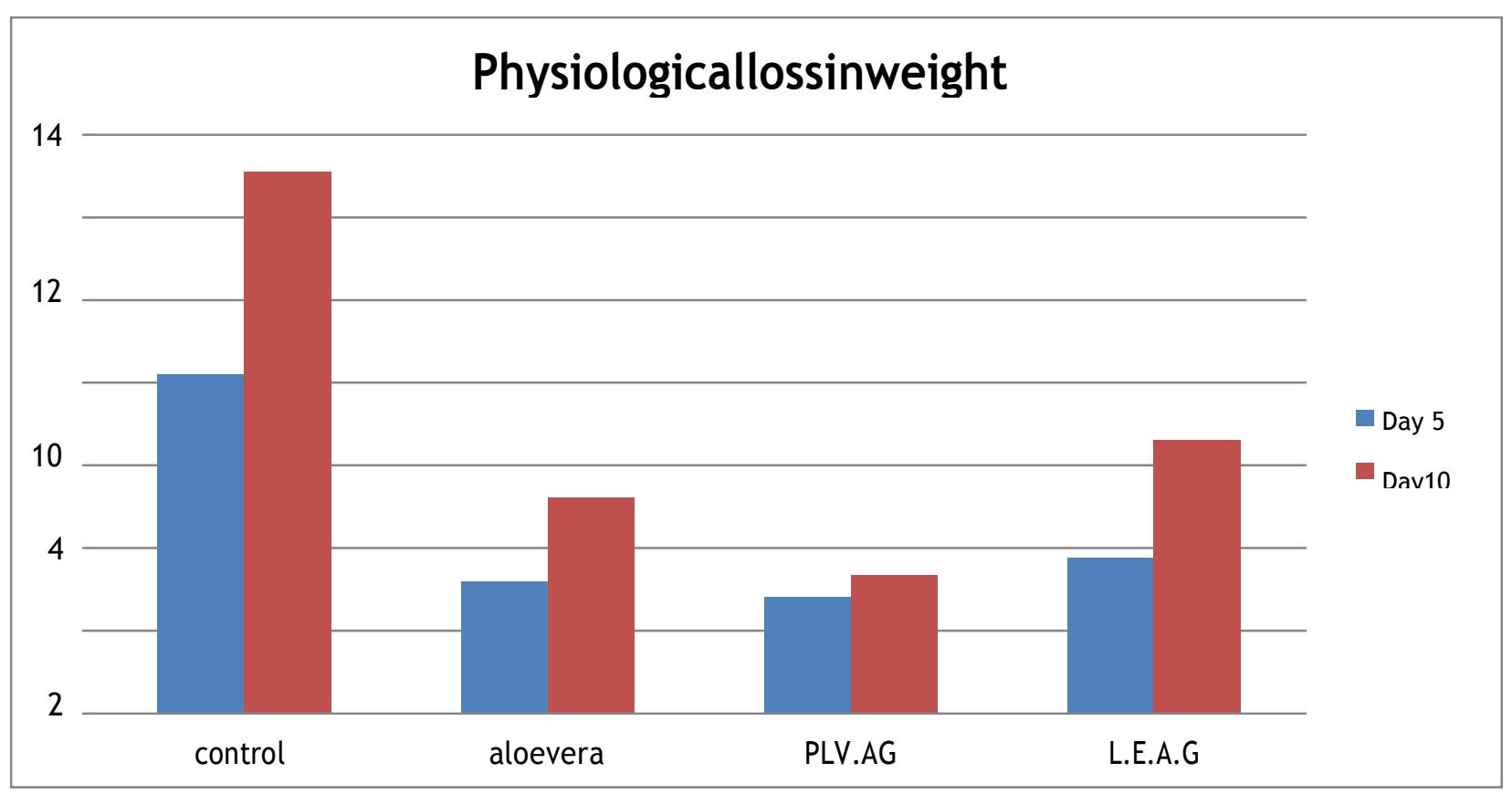

Fig no C:-Effect of Control and Edible coating on Physiological loss in weight of Papaya fruit. 
PLV.AG = Papaya leaf extract incorporated in Aloe gel.

L.E. $A G=$ Papaya leaf extract incorporated in Aloe gel.

\section{SensoryAnalysis:-}

Table No7:-Effect of edible coating on sensory qualities of papaya fruits stored at $30 \pm 3{ }^{0} \mathrm{C}$

\begin{tabular}{|c|c|c|c|}
\hline Type of coating & Colour & Firmness & Taste \\
\hline 0 day & \multicolumn{1}{|c|}{$5 \pm 0$} & $5 \pm 0$ & $3 \pm 0.25$ \\
\hline 5 day storage & \multicolumn{1}{|c|}{$4 \pm 0$} & $2 \pm 0$ & $4 \pm 0$ \\
\hline Control & $1.5 \pm 0.35$ & $3.5 \pm 0.3$ & $4 \pm 0$ \\
\hline Aloe Vera & $3.5 \pm 0.3$ & $4.5 \pm 0.35$ & $3 \pm 0.25$ \\
\hline PLV.AG & $3.5 \pm 0.3$ & $3.5 \pm 0.3$ & $4 \pm 0$ \\
\hline L.E.A.G & $*$ & $*$ & $*$ \\
\hline 10 day storage & $3 \pm 0$ & & $4 \pm 0$ \\
\hline Control & $4 \pm 0$ & $2.5 \pm 0.35$ & $3 \pm 0.25$ \\
\hline Aloe Vera & $3 \pm 0$ & $4 \pm 0$ & $4.5 \pm 0.35$ \\
\hline PLV.AG & & $2 \pm 0$ & \\
\hline L.E.A.G & & & \\
\hline
\end{tabular}

$*$ = complete decay of fruit.

PLV.AG = Papaya leaf extract incorporated in Aloe gel.

L.E. AG = Papaya leaf extract incorporated in Aloe gel.

Estimation of Pectin

Table no 8:-The pectin content is expressed as \% calciumpectate:-

\begin{tabular}{|c|l|l|l|c|}
\hline $\begin{array}{c}\text { Storage Period } \\
(\text { Days })\end{array}$ & Control (\%)) & Aloe Vera (\%) & L.E.A.G (\%) \\
\hline 0 Day & 80 & 80 & 80 & 80 \\
\hline 5 Day & 30 & 62 & 66 & 56 \\
\hline $\begin{array}{l}\text { Day } \\
\text { Day }\end{array}$ & 16 & 48 & 58 & 36 \\
\hline
\end{tabular}

Fig no D: - Effect of Control and Edible coating on\% calcium pectate of Papaya fruit.

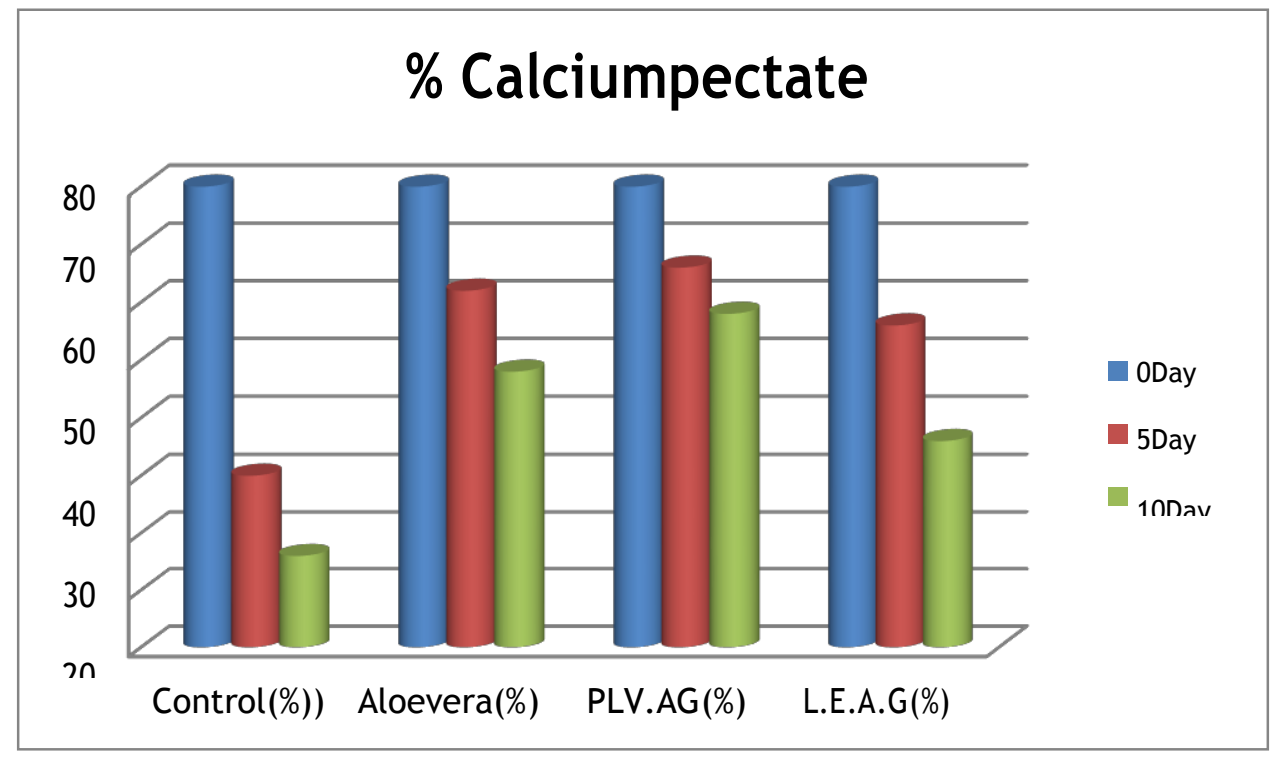

PLV.AG = Papaya leaf extract incorporated in Aloe gel.

L.E. AG = Papaya leaf extract incorporated in Aloe gel. 


\section{Reference:-}

1. Abirami L S S, (2009), Efficacy of chitosan and natural plant extracts on the growth of selected fungal pathogens and control of anthracnose disease of papaya .M.Sc thesis, Sri Sathya Sai University, PrashanthiNilayam.

2. AdetunjiC.O.,FawoleO.B,AfolayanS.S,OlaleyeO.O.AdetunjiJ.B.(2012)EffectsofAloeVeragel coatings on shelf life of Citrus sinensis fruits stored at ambient temperature.

3. Arowora, K.A.1, Williams J.O1, Adetunji, C.O.1, Fawole, O.B.2, Afolayan, S.S.1, Olaleye, O.O.1, Adetunji, J.B.3 and Ogundele, B.A. (January 2013) Effects of Aloe VeraCoatings on Quality Characteristics of Oranges Stored Under Cold Storage Greener Journal of Agricultural Sciences; Vol. 3 (1), pp. 039-047.

4. Asghari M, Ahadi L and Riaie S: (2013),Effect of salicylic acid and edible coating based Aloe Veragel treatment on storage life and postharvest quality of grape (Vitis vinifera L. cv. Gizel Uzum) Intl J Agri Crop Sci. Vol., 5 (23), 2890- 2898.

5. Athmaselvi,K.A, P. Sumitha, and B. Revathy:(2013)Development of Aloe Verabased edible coating for tomato; Int. Agrophys, 27, 369-375.

6. Biale, J. B. 1960: The postharvest biochemistry of tropical and subtropical fruits. Advances in food research 10:293-354

7. Devlieghere F, Vermeullen A \& Debevere J, (2004), Chitosan: Antimicrobial activity, interactions with food components and applicability as a coating on fruits and vegetables, Food Microbiol, 21,703-714.

8. Eshun, K. and He, Q. (2004) .Aloe Vera: a valuable ingredient for the food,pharmaceutical and cosmetic industries: a review. Crit.Rev. Food. Sci. Nutr. 44,91-96

9. Garcia, M.A., M.N Martino and N.E. Zaritzky (1998). Starch-based coatings: Effect on refrigerated strawberry Fragaria ananassa quality. J.Sci. Food Agric., 76:411-420

10. Habeeb F, Shakir E, Bradbury F, Cameron P et al, (2007) Screening methods used to determine the antimicrobial properties of Aloe Vera inner gel,Methods,42,315-320.

11. Hagenmaier, R.D. and Baker, R.A. (1995). Layers of coatings to control weight lossand preserve gloss of citrus fruit. Hortscience 30,296-298.

12. He, Q. J, Changhong, L.J, Kojo, E.J., Tian, Z, (2005).Quality and safety assurance inthe processing of Aloe Vera gel juice. Food control 16,95-104.

13. Jasso de Rodiguez, D.J Herna ndez-castillo, D.J., Rodriguez Garcia, R., Angulo- sa nchez. J.L. (2005). Antifungal activity in vitro of Aloe Vera pulp and liquid fractionagainst plant pathogenic fungi ind. Crop prod., 21,81-87.

14. Lin, D. and Zhao, Y. 2007, "Innovations in the development and application of edible coatings for fresh and minimally processed fruits and vegetables", Comprehensive Reviewsin Food Science and Food SafetyCRFSFS, 6 (3). 60-75,2007.

15. Mattheis J \& Fellman J K, (2000), Impact of modified atmospheric packagingand controlled atmosphere on aroma, flavor and quality of horticulture commodities, Hort Technol,10,pp-507-510.

16. Martinez-Romero D, Serrano M,Valero D And \& Castillo S,(2003), Application deAloe Vera como recubrimicento stobre frutas Yhor taliza, Spainpatent,pp-2003-2937.

17. Martinez-Romero D, Guillén F, Valverde JM, Bailén G, Zapata PJ, Serrano M, CastilloS, Valero D, 2007.Influence of carvacrol on survival of Botrytis cinerea inoculated in table grapes. International Journal Food Microbial.115: 144148.

18. Marpudi, S.L, LSS Abirami, Pushkala R and N Srividya, (2011) Enhancement of storage life and quality maintenance of papaya fruits using Aloe Verabased antimicrobial coating, Indian Journal of Biotechnology vol10,83-89.

19. Martinez-Romero D L,Alburquerque N, Valverde J M,Guillen F, Castillo S et al (2006), Post harvest cherry quality and safety maintenance by Aloe Veratreatment: A new edible coating ,Post harvest Biol Technol,39,93100.

20. Mitra S, (2005), Papaya, in Postharvest physiology and storage of tropical andsubtropical fruits, (CABI Publishing, India), 175-182.

21. Mohamadreza Asghari1, Hojjat Khalili*1, Yusof Rasmi2 , Arash Mohammadzadeh3, (2013) Influence of Postharvest Nitric oxide and Aloe VeraGel Application on Sweet Cheery Quality Indices and Storage Life; International Journal of Agronomy and Plant Production. Vol., 4 (9),2393-2398.

22. M. M. Rahman, M. M. Rahman, N. Absar, and M. A. Ahsan, (2011) "Correlation of Carbohydrate content with the changes inamylase, invertase and -galactosidase activity of ripe mango pulp during storage under different temperatures," Bangladesh Journal of Scientific and Industrial Research, vol. 46, no. 4,pp.443-446. 
23. Ni, Y., Turner, D.; Yates, K. M.; Tizard, I. (2004). Isolation characterization of structural components of Aloe Vera L. leaf pulp Int. Immuno pharmacol. 4, 1745-1755.

24. Pantastico, E. B.; Subramanyam, H.; Phatti, M. B.; Ali, N.; Akamine, E. K. 1975:Harvest indices. In: Pantastico ed., Postharvest physiology, handling, and utilisation of tropical and subtropical fruits and vegetables. Connecticut. AVI Publishing Company, pp.56-75.

25. Singhal V, (1999), Papaya, in Indian agriculture (Indian Data Research Centre, NewDelhi), 169-170.

26. Shelton RM.(1991), Aloe Vera its chemical and therapeutic properties. Int JDermatol.; 30:10:679-83

27. Shweta Chauhan, K.C.Gupta and Mukesh Agrawal, (2014), International JournalOf Current Microbiology And Applied Science, Volume 3 Number 3 pp.632-642.

28. Surjushe A, Vasani R, Saple DG. (2008); Aloe vera: a short review. Indian J Dermatol. 534:163-

29. Vargas M,Pastov C, Chirau A,Clements M C,Julian D \& Gunzalez MartinezC, (2008) Recent advances in edible coatings for fresh and minimally processed fruits, sCrit Rev Food Sci Nutr,48,496-511.

30. W. Hortwitz, (1960) Official and Tentative Methods of Analysis, Association of the Official Agriculture Chemist, Washington, DC,USA. 